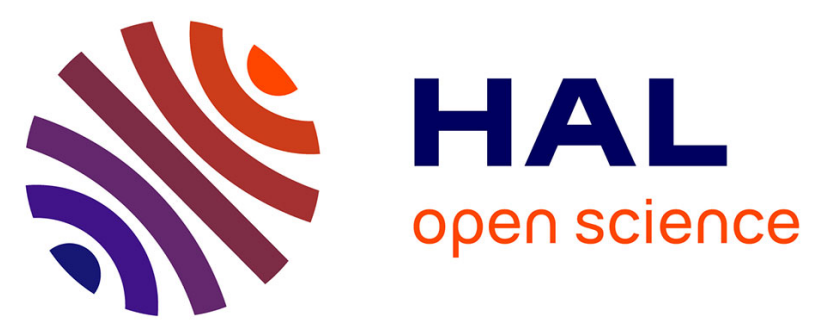

\title{
Uncoupled viral and bacterial distributions in coral reef waters of Tuamotu Archipelago (French Polynesia)
}

\author{
Marc Bouvy, Marine Combe, Yvan Bettarel, Christine Dupuy, Emma
}

Rochelle-Newall, Loic Charpy

\section{- To cite this version:}

Marc Bouvy, Marine Combe, Yvan Bettarel, Christine Dupuy, Emma Rochelle-Newall, et al.. Uncoupled viral and bacterial distributions in coral reef waters of Tuamotu Archipelago (French Polynesia). Marine Pollution Bulletin, 2012, Ahe Atoll and Pearl Oyster Aquaculture in the Tuamotu Archipelago, 65 (10-12), pp.506-515. 10.1016/j.marpolbul.2012.01.001 . hal-01420111

HAL Id: hal-01420111

https://hal.science/hal-01420111

Submitted on 26 Dec 2016

HAL is a multi-disciplinary open access archive for the deposit and dissemination of scientific research documents, whether they are published or not. The documents may come from teaching and research institutions in France or abroad, or from public or private research centers.
L'archive ouverte pluridisciplinaire HAL, est destinée au dépôt et à la diffusion de documents scientifiques de niveau recherche, publiés ou non, émanant des établissements d'enseignement et de recherche français ou étrangers, des laboratoires publics ou privés. 


\title{
Uncoupled viral and bacterial distributions in coral reef waters of Tuamotu Archipelago (French Polynesia)
}

\author{
Marc Bouvy $^{\mathrm{a}, *}$, Marine Combe $^{\mathrm{a}}$, Yvan Bettarel $^{\mathrm{a}}$, Christine Dupuy ${ }^{\mathrm{b}}$, Emma Rochelle-Newall $^{\mathrm{c}}$, \\ Loic Charpy ${ }^{\mathrm{d}}$
}

${ }^{a}$ UMR 5119, ECOSYM - Ecologie des systèmes marins côtiers (UM2, CNRS, IRD, Ifremer, UM1), Université Montpellier 2, Place Eugène Bataillon, Case 093, 34095 Montpellier Cedex 5, France

${ }^{\mathrm{b}}$ Littoral, Environnement et SociétéS (LIENSs), Université de La Rochelle, UMR 6250 CNRS-ULR, 2 rue Olympe de Gouges, 17000 La Rochelle Cedex, France

${ }^{\mathrm{C}}$ UMR 7618, BIOEMCO (UPMC-CNRS-INRA-ENS-IRD-AgroParisTech-Université Paris-Est), Ecole Normale Supérieure, 46 rue d'Ulm, 75005 Paris, France

d UMR LOPB (IRD, CNRS, Université Méditerranée), IRD Centre de Tahiti, BP 529, 98713 Papeete, French Polynesia

\section{A R T I C L E I N F O}

\section{Keywords:}

Virus

Bacteria

Distributions

Strategy lifes

Coral reef waters

\begin{abstract}
A B S T R A C T
This study examined the distribution of virioplankton and bacterioplankton in two coral reef systems (Ahe and Takaroa atolls) in the Tuamotu Archipelago, in comparison with the surrounding oligotrophic ocean. Mean concentrations of $4.8 \times 10^{5}$ and $6.2 \times 10^{5}$ cells ml $^{-1}$ for bacteria and $8.1 \times 10^{6}$ and $4.3 \times 10^{6} \mathrm{VLP}$ (virus-like particle) $\mathrm{ml}^{-1}$ were recorded in Ahe and Takaroa lagoons, respectively. Chlorophyll- $a$ concentrations and dissolved organic matter were higher in Ahe whereas ${ }^{3} \mathrm{H}$ thymidine incorporation rates were higher in Takaroa. First data on lytic and lysogenic strategies of phages in coral reef environments were discussed in this paper. The fraction of visibly infected cells by viruses was negligible regardless of the lagoon station (mean $=0.15 \%$ ). However, the fraction of lysogenic cells ranged between $2.5 \%$ and $88.9 \%$. Our results suggest that the distribution patterns of virioplankton are apparently not coupled to the spatial dynamics of the bacterioplankton communities.
\end{abstract}

(c) 2012 Elsevier Ltd. All rights reserved.

\section{Introduction}

There is no doubt of the ecological importance of bacterioplankton in coral reef systems but the role of virioplankton in these ecosystems has, to our knowledge, yet to be studied. Viruses are the numerically dominant biological entities in the ocean and viral infection is a major structuring process in the dynamics of marine microbial communities (Fuhrman, 1999; Suttle, 2005). Viral lysis of autotrophic and heterotrophic microorganisms influences the rate of nutrient cycling through microbial food webs (Proctor and Fuhrman, 1990; Fuhrman, 1999). Recent studies of marine systems have shown that virus mediated mortality of bacterioplankton is greater in nutrient rich habitats where contact rates with potential hosts are high (Weinbauer, 2004).

Most virioplankton in the environment infect bacterioplankton (bacteriophages or, simply, phages) and, in general, the distributions of viral populations often mirror the bacterial distributions (Hewson et al., 2001; Middelboe et al., 2003). Variability amongst coral reef bacterial communities has been investigated at a variety of spatial and temporal scales (Moriarty, 1979; Moriarty et al., 1985; Paul et al., 1986; Hoppe et al., 1988; Gast et al., 1998) and

\footnotetext{
* Corresponding author. Tel.: +33 467144128.

E-mail address: marc.bouvy@ird.fr (M. Bouvy).
}

significant variations in abundance, activity and composition have been observed over small spatial and temporal scales (Paul et al., 1986; Gast et al., 1998; van Duyl and Gast, 2001; Frias-Lopez et al., 2002; Rohwer et al., 2002). The role of virioplankton in coral reef systems remain relatively unexplored (Seymour et al., 2005; Mari et al., 2007; Dinsdale et al., 2008), as well as the presence and the roles of viruses associated with healthy and diseased corals which warrant further investigation (Weil et al., 2006; Patten et al., 2008). Nothing is known on the mode of viral infections and the life strategy of virioplankton in coral reef systems.

In addition to their role in the mortality of phyto-and bacterioplankton, viral lysis products (e.g., dissolved organic matter (DOM)) from cells through the viral shunt can be taken up by prokaryotes, thereby stimulating the growth of heterotrophic bacterioplankton (Wilhelm and Suttle, 1999; Thingstad, 2000). Tropical coral lagoon systems are also an interesting environment for the study of carbon cycling, as they are often characterized by low nutrient (DOM) and chlorophyll concentrations (RochelleNewall et al., 2008). The recycling of DOM by heterotrophic bacterioplankton is one of the major organic matter transformation pathways and could explain bacterial and viral distributions (Del Giorgio and Davies, 2003). Virioplankton are, therefore, believed to have a significant effect on aquatic environments.

French Polynesia is made up of several groups of islands in the South Pacific gyre with 84 atolls surrounded by oligotrophic 
waters. The lagoons are of great importance to the economy of French Polynesia, where farming of pearl oyster, Pinctada margaritifera, is the major source of export earnings (Andréfouët et al., 2012). Though originally benthic, $P$. margaritifera is now reared on suspended ropes and the resulting interactions with pelagic communities raise questions about the ability of planktonic food webs to sustain this increased animal production. In atoll lagoons, the primary production is mainly achieved by picophytoplankton (Charpy, 1996; Charpy and Blanchot, 1996), whereas the biomass is dominated by low-producing bacteria (Torréton and Dufour, 1996). As both picoplankters are in a size range unavailable to oysters (Pouvreau et al., 1999), phagotrophic protists may act as an intermediate between the dominant picoproduction and bivalves (Loret et al., 2000).

To determine the potential role of virioplankton in bacterioplankton dynamics in coral reef systems, the spatial distribution of virus-like particles (VLP) and bacterial communities was determined in the pelagic zone, as well as the dissolved organic carbon and the chlorophyll- $a$ concentrations within two atoll lagoons in the Tuamotu Archipelago. The fraction of lysogenic bacterial cells (FLC) and the fraction of infected bacterial cells (FIC) were also determined to infer the prevalence of these two modes of infection. A broad study was made of the VLP and bacterial communities in the benthic zone where there is very little data on virioplankton dynamics at tropical latitudes, especially in coral reef systems.

\section{Methods}

\subsection{Study sites and sampling}

This study was conducted in two atolls (Ahe and Takaroa) located $500 \mathrm{~km}$ northeast of Tahiti in the north of the Tuamotu Archipelago between August 20 and 30, 2009 (Fig. 1; see details in Thomas et al., 2010). Ahe lagoon is $142 \mathrm{~km}^{2}$ in area with a maximum depth close to $70 \mathrm{~m}$ and can be defined as a semi-enclosed atoll. There is one deep passage to the ocean in the northwest and there are several reef-flats (inferior to $50 \mathrm{~cm}$ depth) along the reef rim. Four stations were sampled (A1, A3, A9, A11) situated from the south-west (the deepest $A 1$ with more extensive oyster farming) to the north-east (A11 being the shallowest station with less extensive oyster farms). Water samples were collected at three depths for $\mathrm{A} 1(1,10$ and $20 \mathrm{~m})$ and at five depths for the others (1, $10,20,30$ and $40 \mathrm{~m}$ ). Takaroa lagoon is $85 \mathrm{~km}^{2}$ in area with a mean depth of $26 \mathrm{~m}$ ( $\max$ depth $=47.5 \mathrm{~m}$ ). Four stations were sampled (T1, T2, T3, T4) situated from the east (less deep) to the west, with samples taken at three depths $(1,10$ and $20 \mathrm{~m})$. The average water residence time is estimated at $76 \mathrm{~d}$ in Takaroa, twice that reported for Ahe (34 d) by Andréfouët et al. (2001) and Pagès et al. (2001). Dumas et al. (2012) recently characterized the spatial variation of residence and flushing time in different weather conditions.

The sampling stations were selected to test the spatial distributions of bacterioplankton and virioplankton in the lagoon. For comparison, samples were also taken at three depths $(1,10$, and $20 \mathrm{~m})$ outside the two lagoons (about $3.5 \mathrm{~km}$ away) in the euphotic oceanic zone.

At each sampling station, a CTD profiler (YSI 600 XM) was deployed to measure temperature and depth. Water samples for nutrient and viral and bacterial parameters were collected in the morning using a 5-1 Niskin bottle at each depth, placed directly in acid-washed polyethylene bottles and kept in the dark at in situ temperatures until processed in the laboratory within $2 \mathrm{~h}$. Dissolved organic carbon (DOC) analyses were performed on $30 \mathrm{ml}$ subsamples collected in pre-combusted $\left(450^{\circ} \mathrm{C}\right.$ overnight) glass vials, preserved with $35 \mu \mathrm{l} 85 \%$ phosphoric acid. Samples were stored in the dark until analysis using a Shimadzu TOC VCPH analyzer (Rochelle-Newall et al., 2008). Chlorophyll concentrations were determined fluorometrically after filtration of samples onto Whatman GF/F fiberglass filters and directly extracted using methanol (Yentsch and Menzel, 1963). For bacterial and viral parameters, samples were fixed with prefiltered $(0.02 \mu \mathrm{m})$ buffered formaldehyde ( $2 \%$ final concentration), stored in liquid nitrogen $\left(-162{ }^{\circ} \mathrm{C}\right)$ and analyzed on return to Montpellier University.

Sediment cores were taken by diving near station A11 (Ahe atoll; $5 \mathrm{~m}$ depth) using a PVC tube with $30 \mathrm{~mm}$ internal diameter $(n=4)$. Cores were processed immediately after collection, with subsamples taken using $5 \mathrm{ml}$ sterile syringes $(n=3)$. The top centimeter of the core layer was carefully extracted for bacterial and viral analyses.

\subsection{Enumeration of virioplankton and bacterioplankton}

For water samples, the abundance of bacterioplankton was determined by epifluorescence microscopy using fluorochrome 4',6'-diamidino-2-phenylindole (DAPI) (Porter and Feig, 1980). The number of virus-like particles (VLPs) contained in triplicates of 50-200 $\mu$ l samples were determined after particles had been retained on $0.02 \mu \mathrm{m}$ pore-size membranes (Anodisc) and stained with SYBR Gold (Patel et al., 2007). On each slide, 300-600 bacterioplankton and VLPs were counted in 15-20 fields with final numbers giving a precision of $<10 \%$ at $95 \%$ confidence limit.

Morphologies of virioplankton were also determined using transmission electron microscopy (TEM) (Bettarel et al., 2010). Virioplankton contained in $5 \mathrm{ml}$ aliquots of formalin-fixed samples were harvested by ultracentrifugation onto grids ( 400 mesh $\mathrm{Cu}$ electron microscope grids with carbon coated Formvar film) using a Centrikon TST 41.14 swing-out rotor at $120,000 \mathrm{~g}$ for $2 \mathrm{~h}$. Grids were then stained for $30 \mathrm{~s}$ with uranyl acetate (2\%, w/w) and VLP were counted and measured using a JEOL 1200EX TEM at $80 \mathrm{kV}$ and a magnification of 40,000 . The viral populations were divided into three virus capsid sizes: $<60 \mathrm{~nm}$; $60-90 \mathrm{~nm}$; $>90 \mathrm{~nm}$. Three morphotypes were distinguished for classifying tailed virioplankton (Caudovirales) according to their shape. Tailed virioplankton with isomeric heads and long non contractile tails were classified as Siphoviridae. Tailed virioplankton with isomeric heads and contractile tails were classified as Myoviridae. Tailed virioplankton with short tails were classified as Podoviridae (Bettarel et al., 2011).

For the sediment samples, viruses and bacteria were extracted and analysed according to the procedure of Danovaro et al. (2001) and analyzed according to the procedures described above. Aliquots of the fixed sediment samples $(1 \mathrm{ml})$ were diluted with tetrasodium pyrophosphate (Ppi-NaCl; $4 \mathrm{ml} ; 10 \mathrm{mM}$ final concentration) and incubated for $20 \mathrm{~min}$ at $4{ }^{\circ} \mathrm{C}$. Samples were then sonicated three times ( $100 \mathrm{~W}$ for $1 \mathrm{~min}$ ), diluted 200-1000 times with $0.02 \mu \mathrm{m}$ filtered formaldehyde ( $2 \%$ final concentration). This procedure has been shown to extract most VLPs and bacteria from the sediment (Danovaro et al., 2001).

\subsection{Bacterial production (BP)}

For both sediment and overlying water, heterotrophic bacterial production was determined by [methyl- $\left.{ }^{3} \mathrm{H}\right]$-thymidine incorporation (Kirscher and Velimirov, 1999). For water samples, duplicates and one control (zero time) were incubated with (methyl- ${ }^{3} \mathrm{H}$ )-thymidine (47 $\mathrm{Ci} \mathrm{mmol}{ }^{-1}$, Amersham) in the dark at in situ temperature. Incubation time was $60 \mathrm{~min}$, with a final thymidine concentration of $20 \mathrm{nM}$ (saturation condition). It was assumed that isotope dilution was negligible at this concentration (Robarts and Zohary, 1993). Radioactivity was counted by liquid scintillation.

For the sediments, two replicates and one control were incubated with labeled thymidine used at saturation point, at a final 

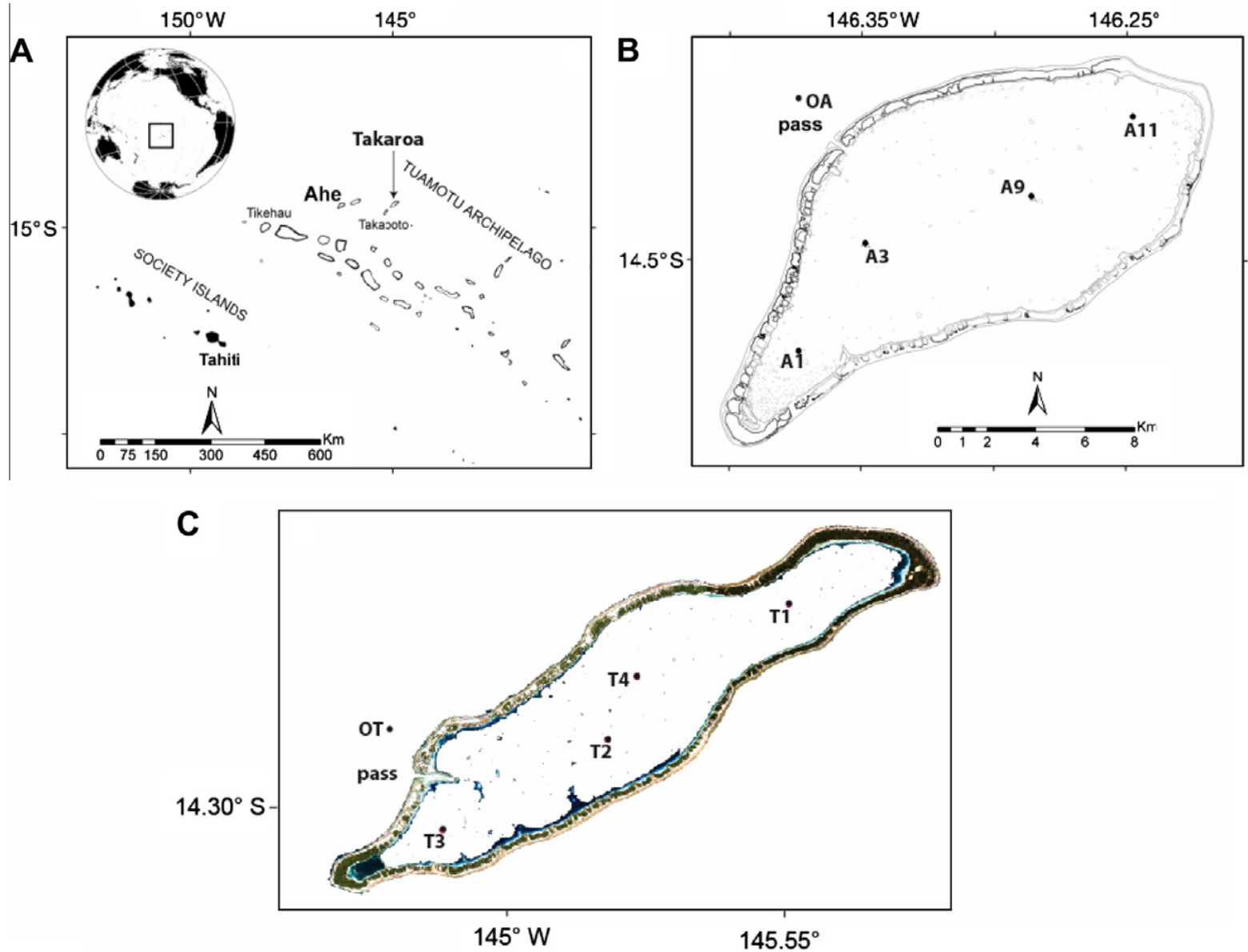

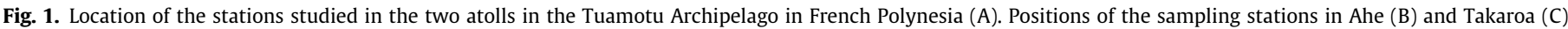
lagoon. OA and OT are defined as oceanic stations, respectively in Ahe and Takaroa atoll system.

concentration of $1000 \mathrm{nM}$ (Haglund et al., 2003). $0.5 \mathrm{~g}$ sub-samples of wet sediment were incubated in $10-\mathrm{ml}$ centrifugation tubes at in situ temperature. Incubation was stopped with formaldehyde after $60 \mathrm{~min}$. Samples were then centrifuged $(8500 \mathrm{~g})$ for $20 \mathrm{~min}$, the supernatant was discarded and the pellet was washed three times with $5 \mathrm{ml}$ of $80 \%$ ethanol. Finally, pellets were washed twice with $5 \mathrm{ml}$ of ice-cold TCA (5\%), filtered onto a $0.2 \mu \mathrm{m}$ pore size membrane filter, transferred to vials with $3 \mathrm{ml}$ of $2 \mathrm{~N} \mathrm{NaOH}$ and heated for $2 \mathrm{~h}$ in a water bath at $100^{\circ} \mathrm{C}$. After cooling, $1 \mathrm{ml}$ of the supernatant was transferred to a scintillation vial and a scintillation cocktail was added. For comparison with the literature, bacterial production was estimated using a conversion factor of $2 \times 10^{18}$ cells produced per mole of thymidine incorporated (Haglund et al., 2003).

\subsection{Viral infection of bacterioplankton}

Two different viral infection strategies were investigated: the frequency of bacteria killed by lytic phages (lytic infection) and the frequency of lysogenic cells (lysogenic infection). To determine the percentage of lytic bacterial cells (fraction of infected cells; FIC), bacterioplankton contained in duplicate $8 \mathrm{ml}$ aliquots of formalin-fixed samples were harvested by ultracentrifugation at 70,000g for $20 \mathrm{~min}$ onto 400 mesh Cu grids, stained for $30 \mathrm{~s}$ with uranyl acetate $(2 \% \mathrm{w} / \mathrm{w})$ and examined at $\times 40,000$ by TEM at $80 \mathrm{kV}$ to distinguish between virus-infected and uninfected bacterial cells (Weinbauer and Höfle, 1998). At least 500 bacterial cells were inspected per grid. To estimate virally-induced bacterial mortality (VIBM), the fraction of infected cells (FIC) was calculated from the fraction of visibly infected cells (FVIC) (expressed as a percentage) using the formula: FIC $=7.11 \times$ FVIC (Weinbauer et al., 2002). Only samples from the water columns were analyzed for viral infection. The fraction of lysogenic bacteria (FLC) was estimated following the method described by Mei and Danovaro (2004), based on the prophage induction in the bacterioplankton from the pelagic zone. For each sample, three subsamples $(10 \mathrm{ml})$ were taken and mitomycin C $\left(1 \mu \mathrm{g} \mathrm{ml}{ }^{-1}\right.$ final concentration, Sigma Chemical Co, No. M-0503) was added to 2 of these, the untreated subsample serving as a control. Both samples were formalin-fixed after being incubated for $12 \mathrm{~h}$ (Mei and Danovaro, 2004; Weinbauer et al., 2003). Prophage induction was calculated as the difference in viral abundance between mitomycin $\mathrm{C}$ treated $(\mathrm{Vm})$ and control incubations $(\mathrm{Vc})$. The fraction of lysogenic bacterioplankton cells (FLC) was calculated as: FLC $(\%)=100[(\mathrm{Vm}-\mathrm{Vc}) /$ $\left(\mathrm{BS} \times \mathrm{BAC}_{\mathrm{to}}\right)$ ], with $\mathrm{BS}=$ burst size (number of virus per bacteria) and $\mathrm{BAC}_{\mathrm{to}}=$ bacterial abundance at the start of the experiment, i.e. before the addition of mitomycin C (Weinbauer et al., 2003).

\subsection{Statistical analysis}

The measured concentrations and distributions of bacterioplankton and virioplankton were compared between the two lagoons and within the water columns. Data were not systematically normally distributed and thus, the non parametric Mann-Whitney test was used to test differences in biological parameters and physico chemical parameters between the two 
atolls. All values are reported as means \pm standard deviation (SD) unless otherwise stated. All statistical analyses were performed using Sigma Stat version 3.5.

\section{Results}

\subsection{Physical and chemical conditions}

The water temperature was comparable in the two atoll lagoons, with a mean of $27.2^{\circ} \mathrm{C}$. In the oceanic zone, values were not significantly different from those recorded in the atolls $\left(26.8 \pm 0.58{ }^{\circ} \mathrm{C}\right.$; Table 1$)$. Chlorophyll- $a$ concentrations were significantly different between the two atolls $(p=0.001)$, with higher values found for Ahe $\left(0.32 \pm 0.10 \mu \mathrm{g} \mathrm{l}^{-1}\right)$. In oceanic zones, chlorophyll concentrations were significantly lower than those in the lagoons $\left(0.13 \pm 0.04 \mu \mathrm{g} \mathrm{l}^{-1} ; p=0.003\right)$ (Table 1$)$. Mean values of DOC concentrations were low and not statistically different $(p>0.05)$ between the stations and the lagoons $(107.6 \pm 53.9 \mu \mathrm{M}$ for Ahe and $87.4 \pm 8.6 \mu \mathrm{M}$ for Takaroa). No significant difference was observed between the concentrations in the lagoons and the oceanic zones $(82.9 \pm 3.9 \mu \mathrm{M})$. Mean concentrations of these physicochemical parameters did not vary significantly according to depth whatever the stations.

\subsection{Planktonic bacterial and viral abundance}

Total bacterial abundances differed significantly between Ahe $\left(6.2 \times 10^{5}\right.$ cells ml $\left.{ }^{-1}\right)$ and Takaroa atolls $\left(4.8 \times 10^{5}\right.$ cells $\left.\mathrm{ml}^{-1}\right)$ $(p=0.028)$ (Table 2). Concentrations of bacterioplankton were significantly higher in the lagoons $\left(5.6 \times 10^{5}\right.$ cells $\left.\mathrm{ml}^{-1}\right)$ than in the ocean $\left(2.9 \times 10^{5}\right.$ cells ml $\left.^{-1}\right)(p=0.001)$. Virus like particle (VLP) concentrations were significantly different between Ahe $\left(4.3 \times 10^{6} \mathrm{VLP} \mathrm{ml}^{-1}\right)$ and Takaroa atolls $\left(8.1 \times 10^{6}\right.$ cells ml $\left.^{-1}\right)$ $(p<0.001)$. However, there was no correlation between the viral and the bacterial concentrations $(r=-0.05 ; p<0.774 ; n=30)$.
There was a significant difference in virioplankton abundance between the lagoon and ocean sites $(p=0.174)$ with a lower mean in oceanic sites $\left(4.2 \times 10^{6} \mathrm{VLP} \mathrm{ml}^{-1}\right)$. The mean virus-to-bacteria ratio (VBR) was 7.6 for Ahe, significantly lower than the ratio (17.6) observed for Takaroa ( $p<0.001$ ) (Table 2). No significant difference in VLP abundance was noted according to the depth and the stations studied inside a lagoon (Figs. 2 and 3). Virioplankton smaller than $60 \mathrm{~nm}$ were clearly dominant at all stations studied inside the lagoon and in the oceanic zones (Table 3). They accounted for nearly $95 \%$ of the total community for all stations, with the exception of station A11 (87.3\%) located in the northern part of the Ahe atoll. There were relatively few virioplankton larger than $90 \mathrm{~nm}$ at all stations (Table 3). Almost 75\% of the total viral community belonged to the Siphoviridae. No significant difference between the viral morphotypes was observed between lagoon stations and oceanic zone. The rest of the community comprised virioplankton from the Myoviridae and Podoviridae families.

\subsection{Benthic bacterial and viral abundances}

Mean of benthic bacterial concentrations were $68 \pm 62 \times 10^{5}$ cells $\mathrm{ml}^{-1}(n=4)$, nearly 10 times more abundant than planktonic bacterial cells observed in the same station (A11). Mean abundances of benthic viruses were 40 times $\left(197 \pm 3 \times 10^{5} \mathrm{VLP} \mathrm{ml}^{-1} ; n=4\right)$ more abundant than virioplankton. The mean virus-to-bacteria ratio (VBR) was higher in the benthic zone $(51.0 \pm 36.4)$ than in the water column $(11.6 \pm 0.4)$ in the same station. The mean rate of ${ }^{3} \mathrm{H}$ thymidine incorporation was 1000 -fold higher in the sediments $\left(10 \pm 3.9 \times 10^{3} \mathrm{pmol}^{-1} \mathrm{~h}^{-1}\right)$ than in the overlying waters $\left(10.5 \mathrm{pmol} \mathrm{l}^{-1} \mathrm{~h}^{-1}\right)$.

\subsection{Planktonic bacterioplankton activity}

The ${ }^{3} \mathrm{H}$ thymidine incorporation rates in bacterial cells were significantly lower $(p<0.001)$ in the Ahe lagoon (mean $=5.9 \pm 3.1$

Table 1

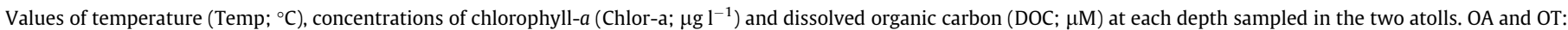
oceanic stations.

\begin{tabular}{|c|c|c|c|c|c|c|c|}
\hline \multicolumn{4}{|l|}{ AHE } & \multicolumn{4}{|l|}{ TAKAROA } \\
\hline Depth (m) & Temp $\left({ }^{\circ} \mathrm{C}\right)$ & Chlor- $a\left(\mu \mathrm{g} \mathrm{l}^{-1}\right)$ & $\overline{\mathrm{DOC}}(\mu \mathrm{M})$ & Depth (m) & Temp $\left({ }^{\circ} \mathrm{C}\right)$ & Chlor- $a\left(\mu \mathrm{g} \mathrm{l}^{-1}\right)$ & $\overline{\mathrm{DOC}}(\mu \mathrm{M})$ \\
\hline \multicolumn{8}{|c|}{ Atoll stations } \\
\hline A1 & & & & $\mathrm{T} 1$ & & & \\
\hline 1 & 27,47 & 0,44 & 95,3 & 1 & 27,12 & 0225 & 99,9 \\
\hline 10 & 27,45 & 0,50 & 168,5 & 10 & 27,28 & 0165 & 99,9 \\
\hline 20 & 27,43 & 0,28 & 97,8 & 20 & 27,28 & 0243 & 95,6 \\
\hline A3 & & & & $\mathrm{T} 2$ & & & \\
\hline 1 & 27,3 & 0,34 & 90,0 & 1 & 27,18 & 0145 & 76,6 \\
\hline 10 & 27,29 & 0,34 & 96,2 & 10 & 27,25 & 0158 & 93,2 \\
\hline 20 & 27,28 & 0,39 & 88,4 & 20 & 27,25 & 0159 & 85,9 \\
\hline A9 & & & & T3 & & & \\
\hline 1 & 27,17 & 0,27 & 84,8 & 1 & 27,24 & 0215 & 79,5 \\
\hline 10 & 27,13 & 0,16 & 83,6 & 10 & 27,25 & 0213 & 75,0 \\
\hline 20 & 27,12 & 0,15 & 259,5 & 20 & 27,19 & 0239 & 84,3 \\
\hline A11 & & & & $\mathrm{T} 4$ & & & \\
\hline 1 & 27,16 & 0,27 & 73,3 & 1 & NA & 0135 & 79,9 \\
\hline 10 & 27,12 & 0,31 & 73,5 & 10 & NA & 0159 & 89,2 \\
\hline 20 & 27,11 & 0,36 & 80,7 & 20 & NA & 0143 & 89,0 \\
\hline Mean & 27.25 & 0.32 & 107.6 & Mean & 27.23 & 0.18 & 87.4 \\
\hline Std & 0.14 & 0.10 & 53.9 & Std & 0.05 & 0.04 & 8.6 \\
\hline \multicolumn{8}{|c|}{ Ocean station } \\
\hline $\mathrm{OA}$ & & & & OT & & & \\
\hline 1 & 26,1 & 0,14 & 80,0 & 1 & NA & 0089 & 82,9 \\
\hline 10 & 27,12 & 0,13 & 88,7 & 10 & NA & 0104 & 85,5 \\
\hline 20 & 27,1 & 0,19 & 83,0 & 20 & NA & 0156 & 77,3 \\
\hline Mean & 26.77 & 0.15 & 83.9 & Mean & NA & 0.12 & 81.9 \\
\hline Std & 0.58 & 0.03 & 4.4 & Std & NA & 0.04 & 4.2 \\
\hline
\end{tabular}


Table 2

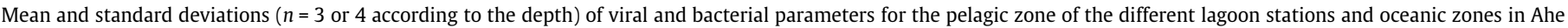
and Takaroa.

\begin{tabular}{|c|c|c|c|c|c|c|c|}
\hline SITE & Bacteria conc. $\left(10^{5}\right.$ cells $\left.\mathrm{ml}^{-1}\right)$ & Virus conc. $\left(10^{6} \mathrm{VLP} \mathrm{ml}^{-1}\right)$ & VBR & ${ }^{3} \mathrm{H}$ thymidine incorporation $\left(\mathrm{pmol} \mathrm{l}^{-1} \mathrm{~h}^{-1}\right)$ & Burst size & FIC (\%) & FLC (\%) \\
\hline \multicolumn{8}{|l|}{ AHE } \\
\hline $\mathrm{A} 1$ & $5.6(2.8)$ & $4.9(1.4)$ & $9.9(3.7)$ & $10.5(5.0)$ & 76 & 0.27 & $88.9(17.1)$ \\
\hline A3 & $6.1(1.5)$ & $0.6(1.1)$ & $7.4(4.2)$ & $4.6(1.4)$ & 19 & 0.23 & $7.9(1.2)$ \\
\hline A9 & $5.8(1.9)$ & $4.7(1.0)$ & $8.7(3.3)$ & $5.4(2.2)$ & 30 & 0.34 & $\mathrm{Nd}$ \\
\hline A11 & $7.1(0.7)$ & $3.8(1.1)$ & $5.3(1.3)$ & $4.9(0.8)$ & 20 & 0.47 & $\mathrm{Nd}$ \\
\hline Mean (lagoon) & 6.2 & 4.3 & 7.6 & 5.9 & 42.1 & 0.32 & Nd \\
\hline Std (lagoon) & 1.7 & 1.1 & 3.4 & 3.1 & 31.6 & 0.11 & Nd \\
\hline OA (ocean) & $3.8(1.1)$ & $2.1(0.4)$ & $5.8(2.9)$ & $4.6(4.5)$ & 0 & 0 & $2.5(0.8)$ \\
\hline \multicolumn{8}{|l|}{ TAKAROA } \\
\hline $\mathrm{T} 1$ & $5.4(1.9)$ & $7.1(0.7)$ & $14.0(4.7)$ & $13.4(4.5)$ & 26 & 0.31 & $7.4(1.0)$ \\
\hline $\mathrm{T} 2$ & $4.6(0.9)$ & $7.7(3.2)$ & $16.0(3.9)$ & $8.1(1.1)$ & 30 & 0.35 & $\mathrm{Nd}$ \\
\hline T3 & $3.6(1.2)$ & $7.5(3.1)$ & $21.5(8.2)$ & $8.8(0.7)$ & 0 & 0 & $\mathrm{Nd}$ \\
\hline $\mathrm{T} 4$ & $5.6(2.2)$ & $7.8(6.3)$ & $12.6(9.5)$ & $15.3(15.4)$ & 25 & 0.28 & $\mathrm{Nd}$ \\
\hline Mean (lagoon) & 4.8 & 8.1 & 17.6 & 9.3 & 20.2 & 0.23 & Nd \\
\hline Std (lagoon) & 1.6 & 2.5 & 5.2 & 3.2 & 13.6 & 0.16 & Nd \\
\hline OT (ocean) & $1.9(1.1)$ & $6.4(1.1)$ & $39.1(18.4)$ & $6.7(3.2)$ & 0 & 0 & $8.0(2.2)$ \\
\hline
\end{tabular}

VBR: virus to bacteria ratio; FIC: frequency of infected cells; FLC: frequency of lysogenic cells.

OA and OT: oceanic stations.

Nd: not determined.

$\mathrm{pmol}^{-1} \mathrm{~h}^{-1}$ ) than in the Takaroa lagoon (mean $=9.3 \pm 3.2$ pmol $l^{-1} \mathrm{~h}^{-1}$ ). The mean values for the oceanic zones, were lower (4.6 and $6.7 \mathrm{pmol}^{-1} \mathrm{~h}^{-1}$ ), but not significantly different from those observed in lagoons $(p=0.289)$.

\subsection{Life strategies of virioplankton}

In the water column, the fraction of infected cells (FIC) ranged from $0 \%$ to $0.5 \%$ (mean $=0.15 \%$ ). No significant difference of FIC was observed regardless of the station $(p=0.85)$ and the atoll $(p=0.75)$. At the oceanic stations, no bacterial cells were infected at any site or depth sampled. The burst size (the number of VLP counted in a bacterial cell) varied significantly with the highest values observed in Ahe lagoon (mean $=42.1$ ) compared to Takaroa lagoon (17.6). The mean burst size was $28.2 \pm 21.5$ (Table 2 ).

The fraction of lysogenic cells (FLC) differed significantly between the stations inside an atoll, with the fraction of lysogenic cells in the total bacterial community ranging from $2.5 \%$ (station A11) to $88.9 \%$ (station A1) (Table 2). Unlike the results for lytic infection, all the bacterial communities from the ocean stations had a significant fraction of lysogenic cells (2.5-8\%).

After compiling all the data, no significant correlation was observed between bacterial and viral abundance or between ${ }^{3} \mathrm{H}$-thymidine incorporation rates and bacterial abundance. Bacterial abundances and chlorophyll concentrations were not significantly correlated, regardless of site, nor were the bacterial abundances and the DOC concentrations. The only significant correlation observed was between the ${ }^{3} \mathrm{H}$ thymidine incorporation rates and DOC concentrations in the Takaroa atoll $(r=0.594 ; p<0.04)$.

\section{Discussion}

Many studies have dealt with the viral compartment in tropical ecosystems (Seymour et al., 2005; Dinsdale et al., 2008; Weinbauer et al., 2010) by exploring the relationship between bacterial and viral distributions. This study provides new data on these two biological components in two coral reef systems, and especially on a variety of viral parameters. To the best of our knowledge, this study provided the first data on lytic and lysogenic strategies of phages in coral reef environments. Other secondary results reported viral and bacterial parameters in the benthic compartment (at one site), knowing that this domain is seldom studied in these systems (e.g., Paul et al., 1993; Patten et al., 2008).
Bacterial numbers in the water column overlying coral reefs (e.g., in the northern Great Barrier Reef) are around 2$6 \times 10^{5}$ cells $\mathrm{ml}^{-1}$ (Moriarty, 1979). Levels of bacterial production and activity are generally higher above coral reefs than in the surrounding waters (Moriarty et al., 1985; Hoppe et al., 1988) owing to the high concentrations of dissolved and particulate organic matter that are released into the overlying reef waters by corals (Ferrier-Pages et al., 1998; van Duyl and Gast, 2001) and benthic algae (Ducklow, 1990). The relationship between production $\left({ }^{3} \mathrm{H}\right.$ incorporation rates) and DOC concentrations was only observed in this study in the Takaroa atoll $(r=0.594 ; p=0.04 ; n=30)$. In the Ahe lagoon, the high concentrations observed in A9 at a depth of $20 \mathrm{~m}$ are potentially due to sedimentary release of potentially low bioavailabilily DOC. Similarly, at station A1, located closer to the atoll rim, the inputs of coral mucus derived DOC should not be ignored (Wild et al., 2004). Rochelle-Newall et al. (2008), working in a barrier reef system proposed that the shifts in the degree of coupling between dissolved primary production and hence, DOC concentrations and bacterial activity in the water column were due to inputs from coral reef mucus or from other inputs of terrestrial origin. In our work, it is probable that the terrestrial inputs were minimal, as evidenced by the low DOC concentrations. Mari et al. (2007) and Weinbauer et al. (2010) also pointed out that the residence time of a water mass can also impact bioavailability of DOC to bacteria. Although it is difficult to accurately pinpoint the sources of these relatively high DOC concentrations, it is probable, given the relatively constant bacterial abundance and activity measurements at these two stations that the DOC was not of high bioavailability. This highlights the more productive environment in the Takaroa versus the Ahe atoll, probably owing to a higher water residence time than that calculated for the Ahe atoll (Andréfouët et al., 2001; Dumas et al., 2012). Lower bacterial abundances were reported in the oceanic stations compared to the atoll stations, corroborating the results from previous studies (e.g., Torréton, 1999). However, no relationship was found in this study between bacterial abundance and chlorophyll- $a$ concentrations although bacterial production is often linked to primary production in reef systems (Rochelle-Newall et al., 2008) and many other pelagic environments (e.g., Cole et al., 1988).

Concentrations of virioplankton were similar to those occurring in near-shore oceanic coral reefs (Seymour et al., 2005; Mari et al., 2007; Dinsdale et al., 2008; Patten et al., 2011). In Ahe and Takaroa atolls, the abundances of virioplankton (min-max, 1.1- 

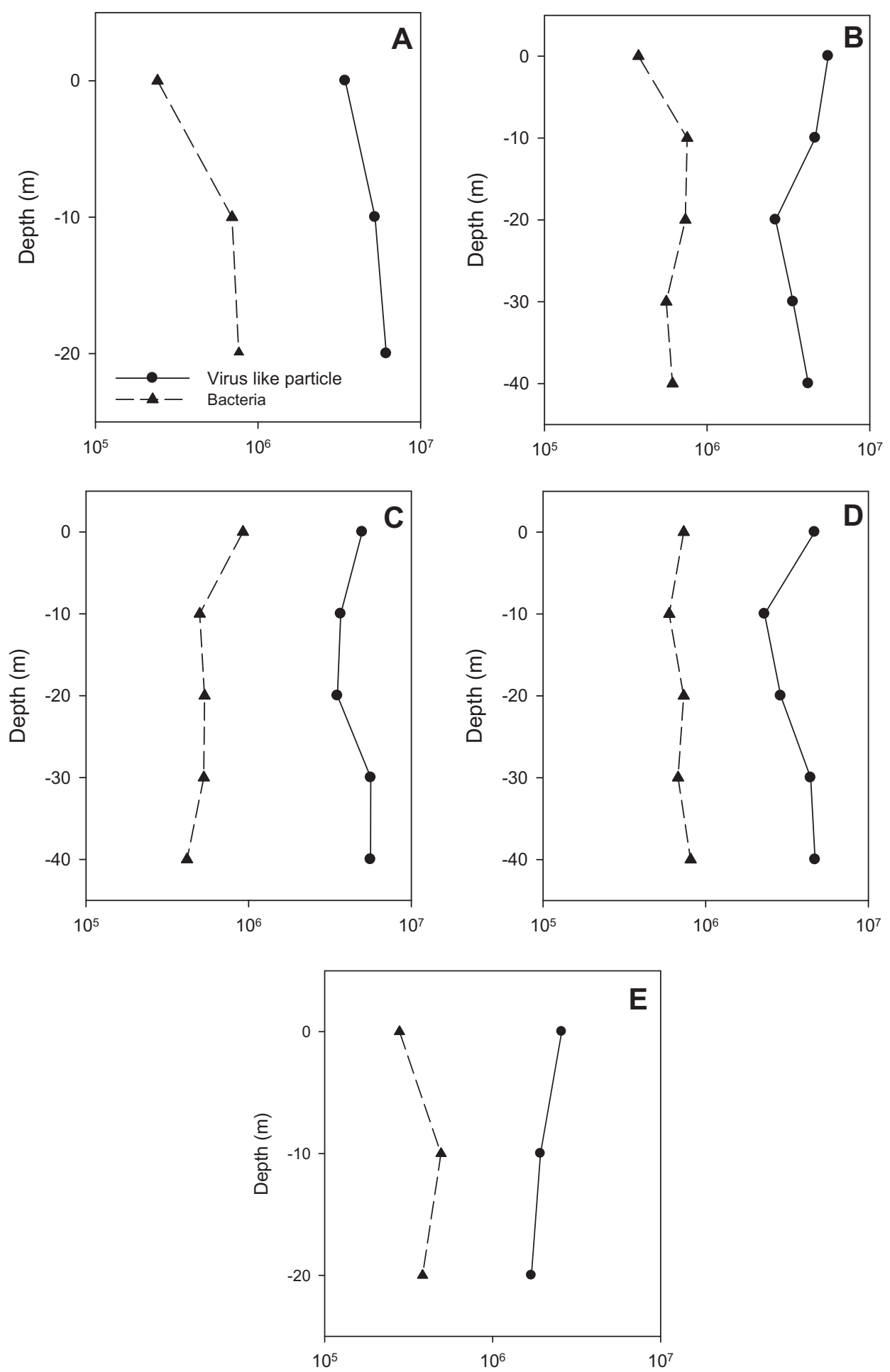

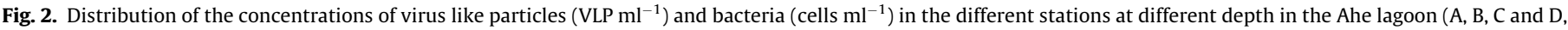
respectively for A1, A3, A9 and A11) and in oceanic zone (E for OA) in August 2009.

$\left.72.0 \times 10^{7} \mathrm{VLPs} \mathrm{ml}^{-1}\right)$ were within the usual range $\left(10^{7}-10^{8} \mathrm{ml}^{-1}\right)$ observed for temperate productive systems (Weinbauer, 2004). VLP concentrations were significantly higher $(p<0.05)$ in the lagoon than in the oceanic zones, confirming that viral abundances tend to be greater in productive, nutrient rich environments (Weinbauer et al., 1993). The results also showed that VLPs were more abundant in the Takaroa lagoon than in the Ahe lagoon, suggesting that virus abundance may be linked to the water residence time. Most (95\%) virioplankton from pelagic environments in this study were smaller than $60 \mathrm{~nm}$ in diameter. Similar results were reported in the sea at various latitudes, including the French Atlantic coast (Auguet et al., 2006), Southern California (Cochlan et al., 1993), the Adriatic Sea (Weinbauer and Peduzzi, 1995), the Alboran Sea (Alonso et al., 2001), the Great Barrier Reef (Davy and Patten, 2007), and the Bach Dang estuary in Vietnam (Bettarel et al., 2011), indicating relative homogeneity in viral capsid size 

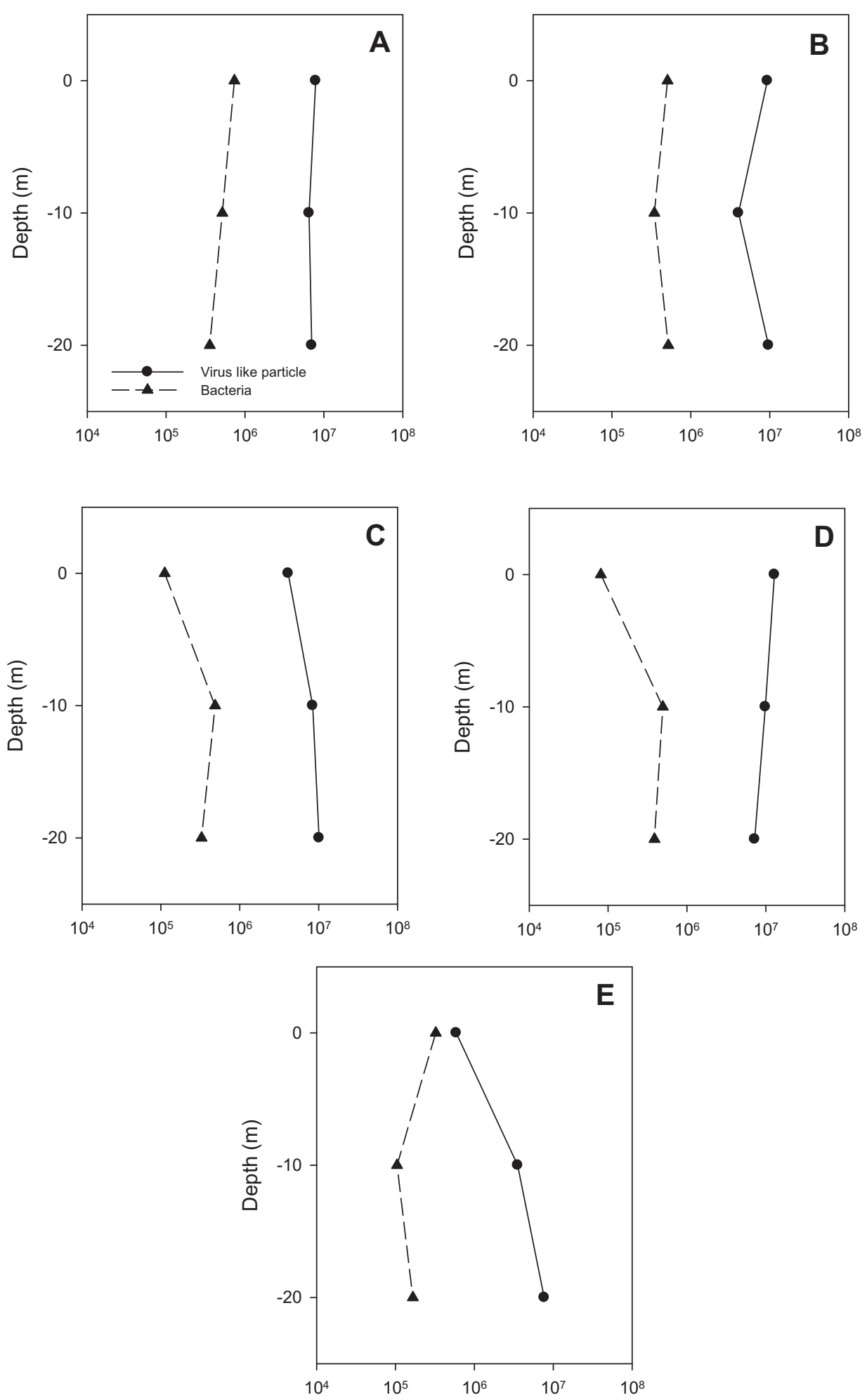

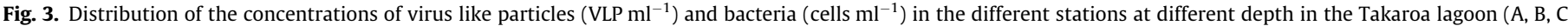
and D, respectively for T1, T2, T3 and T4) and in oceanic zone (E for OT) in August 2009.

on a global scale. Most of the virioplankton belonged to the Siphoviridae characterized by a long flexible tail, confirming that 96\% of all isolated phages have a tail (Ackermann, 2001).

VLP and bacterioplankton abundances did not show significant variability in most of the water columns (Figs. 2 and 3), and the slight variability in abundance with depth was generally close to the average coefficient of variation of viral and bacterial counted using epifluorescence microscopy (average CV =20\%). It was not, therefore, possible to detect any statistically significant relationship between bacterial and viral abundances in this study.

The mean virus-to-bacteria ratio (VBR) was significantly lower in Ahe than in Takaroa $(p<0.001)$ ( 7.6 and 17.6 , respectively). This is consistent with the hypothesis that the VBR is likely to increase in environments that favor fast bacterial growth and high 
Table 3

Distribution of the three caudate virus forms and of three virus size in the different stations A (Ahe lagoon) and T (Takaroa lagoon) and in the two oceanic zones in August 2009.

\begin{tabular}{llll}
\hline Station & \% Myoviridae & \% Siphoviridae & \% Podoviridae \\
\hline A1 & 10.0 & 78.0 & 12.0 \\
A3 & 12.8 & 71.8 & 15.4 \\
A9 & 14.2 & 66.7 & 19.1 \\
A11 & 11.1 & 75.6 & 13.3 \\
OA & 12.7 & 74.5 & 12.8 \\
T1 & 14.5 & 75.0 & 10.5 \\
T2 & 11.3 & 75.1 & 13.6 \\
T3 & 8.6 & 79.3 & 12.1 \\
T4 & 10.2 & 83.6 & 6.2 \\
OT & 7.5 & 87.5 & 5.0 \\
& Small $(<60 \mathrm{~nm}) \%$ & Median $(60-90 \mathrm{~nm}) \%$ & Large $(>60 \mathrm{~nm}) \%$ \\
\cline { 2 - 4 } A1 & 90.0 & 10.0 & 0.0 \\
A3 & 95.1 & 4.9 & 0.0 \\
A9 & 93.1 & 6.9 & 0.0 \\
A11 & 87.3 & 10.9 & 1.8 \\
OA & 94.3 & 5.7 & 0.0 \\
T1 & 90.4 & 5.8 & 3.8 \\
T2 & 94.6 & 1.8 & 3.6 \\
T3 & 92.9 & 7.1 & 0.0 \\
T4 & 92.0 & 6.0 & 2.0 \\
OT & 95.0 & 3.3 & 1.7
\end{tabular}

OA and OT: oceanic stations. Number of viruses counted for this analysis varied from 95 to 112 according to their abundance.

production (Wommack and Colwell, 2000; Bonilla-Findji et al., 2009). This result also confirms that the Takaroa atoll can be defined as a more productive lagoon system than the Ahe atoll. In most aquatic environments, viral abundance is closely correlated to bacterial biomass (Drake et al., 1998; Filippini and Middelboe, 2007) and activity (Heldal and Bratbak, 1991; Middelboe et al., 2003). These positive relationships suggest that viral replication relies strongly on the host abundance and metabolism (Danovaro et al., 2008). Nevertheless, bacterial abundance distribution appeared to be independent of the virus abundance in Ahe and Takaroa (Fig. 4), with no coupling between the patterns of the two variables (regression coefficient $r=0.008 ; p=0.963 ; n=36$ ). As concluded by Dinsdale et al. (2008), these results suggest that the characteristics of these relationships are not static but may be associated with the local conditions in each atoll. The reason for this lack of coupling may also be due to the dominance of virioplankton from sources other than bacterioplankton, such as cyanobacteria (Synechococcus and Prochlorococcus), which are of the same order of magnitude as the abundance of bacterioplankton at the study sites (Thomas et al., 2010; Boury et al., 2012).

The two major viral reproductive strategies are lysogeny (bacteria containing inductible prophages) and lytic viral infection (bacteria in a lytic stage of infection). Our results indicate that virioplankton are not the main agent of bacterial mortality via the lytic cycle. Fractions of infected bacterial cells (FIC) were all extremely low (mean $=0.15 \%$ ), among the lowest recorded in both marine and freshwater systems [see Table 6 in Weinbauer (2004)], regardless of the depth sampled. Nevertheless, to determine how many bacterial cells need to die to maintain the standing stock of virioplankton, it is also necessary to know how many virioplankton are released when one cell lyses. This is the burst size. An average burst size of 25 has been calculated for natural marine communities (Wommack and Colwell, 2000), and this study confirms this for the few infected cells analyzed by TEM (mean burst size $28.2 \pm 21.5$ ). This low percentage of infected cells may be attributed to the virucidal properties of solar radiation, especially UV wavelengths, which are often reported to have a significant effect on viral stocks and infectivity (Bettarel et al., 2006). High FLC

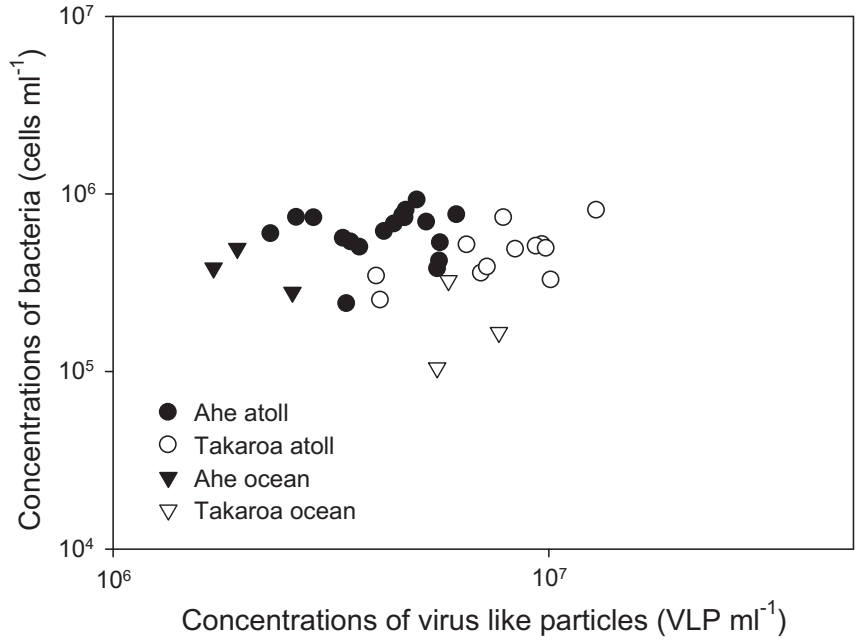

Fig. 4. Distribution of virus like particle and bacteria in lagoon and ocean of the two atolls (Ahe and Takaroa). Regression coefficient between the two variables: $r=0.008 ; p=0.963 ; n=36$.

was reported for some stations (close to $8 \%$ at stations A3 and T1), with the highest value at station A1 ( $88 \pm 17 \%$; Table 2 ).

Lysogeny is thought to be a strategy for virus propagation in systems with poor growth conditions for their bacterial hosts that would be unfavorable for their replication (Weinbauer et al., 2003; Fuhrman, 1999). Mitomycin C and UVC radiation are the most powerful agents inducing the lytic cycle in lysogenized bacterial communities (Ackermann and DuBow, 1987). Weinbauer and Suttle (1999) found that solar radiation caused prophase induction in $86 \%$ of the samples. This may well explain the low percentages of FLC reported in the oceanic zone in the study (2.5-8\%), where there was probably continuous prophase induction due to the high solar radiation, releasing virioplankton (lytic cycle) outside the bacterial cells. Weinbauer (2004) reported that lysogeny in natural communities as determined by prophage induction due to mitomycin $C$ ranged from not detectable to almost 100 . Given the small dataset in this study, it is only possible to suggest that lysogeny is an advantage in situations where the bacterial abundance is insufficient, especially owing to the oligotrophic nutrient concentrations. This conclusion clearly merits further study in coral reef systems.

The potentially small contribution of virioplankton to the control of bacterioplankton may be associated with strong predation pressure from protists. The lack of coupling between bacterioplankton and virioplankton and the very low FIC\% observed in this study suggest that the release of labile organic material from dead bacterial cells (viral shunt) did not appear to be the major factor source of nutrient regeneration. This conclusion differs from results published for temperate coastal regions demonstrating the viral shunt is an essential source of labile organic carbon in many ecosystems (Fuhrman, 1999; Wilhelm and Suttle, 1999; Suttle, 2005).

Bacterial and viral parameters were also studied in the benthic compartment at one site of Ahe. Few data are available about coral reef sediment (e.g., Paul et al., 1993; Patten et al., 2008), especially for bacterial production. Our values of benthic bacterial production $\left(5.2 \times 10^{11}\right.$ cells $\left.1^{-1} \mathrm{~d}^{-1}\right)$ were within the range of values from marine littoral sediments ( 1.5 to $8.7 \times 10^{11}$ cells $1^{-1} \mathrm{~d}^{-1}$; Gulf of Riga; Tuomi et al., 1999). These values were significantly lower than those reported from freshwater sediments in tropical zones $\left(1.9 \times 10^{12}\right.$ cells $\mathrm{l}^{-1} \mathrm{~d}^{-1}$; Bettarel et al., 2006). When compared to the pelagic bacterial production at the same station A11 $\left(3.1 \times 10^{8}\right.$ cells $\left.\mathrm{l}^{-1} \mathrm{~d}^{-1}\right)$, benthic bacterial production was higher 
and seemed to be as significant as in elemental cycling by heterotrophic metabolism. As for all other studies where virus have been studied in both water column and sediment compartments (Hewson et al., 2001; Mei and Danovaro, 2004; Weinbauer, 2004), abundances in sediment exceeded those in water column by 2000. Mei and Danovaro (2004) recently calculated from the literature that a mean benthic-to-pelagic ratio of 20 for viral abundance in both marine and freshwater systems. In this study, the counts gave a ratio of 40 . High abundances of virus in sediments suggest that they are important players in benthic systems but the limited observations available on the role of viruses in sediment tend to be conflicting (Filippini and Middelboe, 2007). In freshwater sediment, Filippini et al. (2006) and Bettarel et al. (2006) reported high viral abundance and an absence of infected bacterial cells. The high VBR found in Ahe atoll (mean of 51) confirms that viruses in benthic environments are an apparently dynamic and potentially ecologically relevant element, within reef ecosystems.

The characteristics of the bacterial and viral communities in the two atolls depend on the characteristics of the seawater, which are affected by regional oceanographic differences, including local circulation, effects of lagoons, run-off from the land and the community structure in the benthic environment, including the activities of the many large oyster farms. Given increasing concern about the widespread decline of the world's coral reefs (Hoegh-Guldberg, 1999; Knowlton, 2001; Gardner et al., 2003), it would be advisable to take into account the potential importance of virioplankton within these systems. Although these results should be interpreted with caution since they were obtained during only one season, the distribution patterns of virioplankton are apparently not coupled to the spatial dynamics of the bacterioplankton communities. Viral infection is, therefore, probably not the major agent responsible for bacterial mortality in these coral reef systems.

\section{Acknowledgements}

This work was supported by the European Development Fund, in collaboration with the Service de la Perliculture and the University of French Polynesia. We should like to thank P. Calquin and P. Bonin for their valuable help in collecting samples. Constructive comments and suggestions were provided by the reviewers.

\section{References}

Ackermann, H.W., 2001. Frequency of morphological phage description in the year 2000. Arch. Virol. 146, 843-857.

Ackermann, H.W., DuBow, M.S., 1987. Viruses of Prokaryotes, Natural Groups of Bacteriophages. vol. 2. CRC Press.

Alonso, M., Jimenez-Gomez, F., Rodriguez, J., Borrego, H., 2001. Distribution of viruslike particles in an oligotrophic marine environment (Alborean Sea, Western Mediterranean). Microb. Ecol. 42, 407-415.

Andréfouët, S., Charpy, L., Lo-Yat, A., Lo, C., 2012. Recent reseach for pearl oyster aquaculture management in French Polynesia. Mar. Pollut. Bull. 65, 407-418.

Andréfouët, S., Pagès, J., Tartinville, B., 2001. Water renewal time for classification of atoll lagoons in the Tuamotu Archipelago (French Polynesia). Coral Reefs 20, 399-408.

Auguet, J.C., Montanie, H., Lebaron, P., 2006. Structure of virioplankton in the Charente estuary (France): transmission electron microscopy versus pulsed field gel electrophoresis. Microb. Ecol. 5, 197-208.

Bettarel, Y., Bouvy, M., Dumont, C., Sime-Ngando, T., 2006. Virus-bacterium interactions in water and sediment of West African inland aquatic systems. Appl. Environ. Microbiol. 72, 5274-5282.

Bettarel, Y., Desnues, A., Rochelle-Newall, E., 2010. Lytic failure in cross-inoculation assays between phages and prokaryotes from three aquatic sites of contrasting salinity. FEMS Microbiol. Lett. 311, 113-118.

Bettarel, Y., Bouvier, T., Agis, M., Bouvier, C., Chu, T.V., Combe, M., Mari, X., Nghiem, M.N., Nguyen, T.T., Pham, T.T., Pringault, O., Rochelle-Newall, E., Torréton, J.-P., Tran, H.Q., 2011. distribution and life strategies in the Bach Dang estuary, Vietnam. Microb. Ecol. 62, 143154.

Bonilla-Findji, O., Herndl, G.J., Gatusso, J.P., Weinbauer, M.G., 2009. Viral and flagellate control of prokaryotic production and community structure in offshore Mediterranean waters. Appl. Environ. Microbiol. 75, 4801-4812.
Bouvy, M., Dupuy, C., Pagano, M., Barani, A., Charpy, L., 2012. Do human activities affect the picoplankton structure of the Ahe atoll lagoon (Tuamotu Archipelago, French Polynesia)? Mar. Pollut. Bull. 65, 516-524.

Charpy, L., 1996. Phytoplankton biomass and production in two Tuamotu Atoll lagoons (French Polynesia). Mar. Ecol. Prog. Ser. 145, 133-142.

Charpy, L., Blanchot, J., 1996. Prochlorococcus contribution to phytoplankton biomass and production of Takapoto Atoll (Tuamotu Archipelago). C.R. Acad Sci. Paris 319, 131-137.

Cochlan, W.P., Wikner, J., Steward, G.F., Smith, D.C., Azam, F., 1993. Spatial distribution of viruses, bacteria and chlorophyll- $a$ in neritic, oceanic and estuarine environments. Mar. Ecol. Prog. Ser. 92, 77-87.

Cole, J.J., Findlay, S., Pace, M.L., 1988. Bacterial production in fresh and saltwater ecosystems: a cross-system overview. Mar. Ecol. Prog. Ser. 43, 1-10.

Danovaro, R., Dell'anno, A., Trucco, A., Serresi, M., Vanucci, S., 2001. Determination of virus abundance in marine sediments. Appl. Environ. Microbiol. 67, 13841387.

Danovaro, R., Dell'Anno, A., Corinaldesi, C., Magagnini, M., Noble, R., Tamburini, C., Weinbauer, M., 2008. Major viral impact on the functioning of benthic deep-sea ecosystems. Nature 454, 1084-1088.

Davy, J.E., Patten, N.L., 2007. Morphological diversity of virus-like particles within the surface microlayer of scleractinian corals. Aquat. Microb. Ecol. 47, 37-44.

Del Giorgio, P.A., Davies, J., 2003. Patterns in dissolved organic matter availability and consumption across aquatic ecosystems. In: Findlay, S., Sinsabaugh, R.L. (Eds.), Aquatic Ecosystems: Interactivity of Dissolved Organic Matter. Academic Press, Amsterdam, pp. 399-424.

Dinsdale, E.A., Pantos, O., Smrigs, S., Edwards, R.A., Angly, F., et al., 2008. Microbial ecology of four coral atolls in the northern line islands. PLoS ONE 3, 1-17.

Drake, L.A., Choi, K.H., Haskell, A.G.E., Dobbs, F.C., 1998. Vertical profiles of virus-like particles and bacteria in the water column and sediments of Chesapeake Bay, USA. Aquat. Microb. Ecol. 16, 17-25.

Ducklow, H.W., 1990. The biomass, production and fate of bacteria in coral reefs. In: Dubinsky, Z. (Ed.), Coral Reefs. Elsevier, Amsterdam, pp. 265-290.

Dumas, F., Le Gendre, R., Thomas, Y., Andréfouët, S., 2012. Tidal flushing and wind driven circulation of Ahe atoll lagoon (Tuamotu Archipelago, French Polynesia) from in situ observations and numerical modelling. Mar. Pollut. Bull. 65, 425440.

Ferrier-Pages, C., Gattuso, J.P., Cauwet, G., Jaubert, J., Allemand, D., 1998. Release of dissolved organic matter and nitrogen by the zooxanthellate coral Galaxa fascicularis. Mar. Ecol. Prog. Ser. 172, 263-274.

Filippini, M., Middelboe, M., 2007. Viral abundance and genome size distribution in the sediment and water column of marine and freshwater ecosystems. Microb. Ecol. 60, 397-410.

Filippini, M., Buesing, N., Bettarel, Y., Sime-Ngando, T., Gessner, M.O., 2006. Infection paradox: high abundance but low impact of freshwater benthic viruses. Appl. Environ. Microbiol. 72, 4893-4898.

Frias-Lopez, J., Zerkle, A.L., Bonheyo, G.T., Fouke, B.W., 2002. Partitioning of bacterial communities between seawater and healthy, black band diseased, and dead coral surfaces. Appl. Environ. Microbiol. 68, 2214-2228.

Fuhrman, J.A., 1999. Marine viruses and their biogeochemical and ecological effects. Nature 399, 541-548.

Gardner, T.A., Cote, I.M., Gill, J.A., Grant, A., Watkinson, A.R., 2003. Long-term regionwide declines in Caribbean corals. Science 301, 958-960.

Gast, G.J., Wiegman, S., Wieringa, E., van Duyl, F.C., Bak, R.P.M., 1998. Bacteria in coral reef water types: removal of cells, stimulation of growth and mineralization. Mar. Ecol. Prog. Ser. 167, 37-45.

Haglund, A.-L., Lantz, P., Tornblom, E., Tranvik, L., 2003. Depth distribution of active bacteria and bacterial activity in lake sediment. FEMS Microbiol. Ecol. 46, 3138.

Heldal, M., Bratbak, G., 1991. Production and decay of viruses in aquatic environments. Mar. Ecol. Prog. Ser. 72, 205-212.

Hewson, I., O’Neil, J.M., Fuhrman, J.A., Dennison, W.C., 2001. Virus-like particle distribution and abundance in sediments and overlaying waters along eutrophication gradients in two subtropical estuaries. Limnol. Oceanogr. 46, 1734-1746.

Hoegh-Guldberg, O., 1999. Coral bleaching, climate change and the future of the worlds coral reefs. Mar. Freshw. Res. 50, 839-866.

Hoppe, H.G., Schramm, W., Bacold, P., 1988. Spatial and temporal distribution of pelagic microorganisms and their proteolytic activity over a partly destroyed coral reef. Mar. Ecol. Prog. Ser. 44, 95-102.

Kirscher, A.K.T., Velimirov, B., 1999. Benthic bacterial secondary production measured via simultaneously 3H-thymidine and 14C-leucine incorporation and its implication for the carbon cycle of a shallow macrophytic-dominated black water system. Limnol. Oceanogr. 44, 1871-1881.

Knowlton, N., 2001. The future of coral reefs. Proc. Natl. Acad. Sci. USA 98, 54195425.

Loret, P., Le Gall, S., Dupuy, C., Blanchot, J., Pastoureaud, A., Delesalle, B., Caisey, X., Jonquières, G., 2000. Heterotrophic protists as a trophic link between picocyanobacteria and the peral oyster Pinctada margaritifera in the Takapoto lagoon (Tuamotu Archipelago, French Polynesia). Aquat. Microb. Ecol. 22, 215-226.

Mari, X., Kerros, M.E., Weinbauer, M.G., 2007. Virus attachment to transparent exopolymeric particles along trophic gradients in the southwest lagoon in New Caledonia. Appl. Environ. Microbiol. 73, 5245-5252.

Middelboe, M., Glud, R.N., Finster, K., 2003. Distribution of viruses and bacteria in relation to diagenetic activity in an estuarine sediment. Limnol. Oceanogr. 48 1447-1456. 
Mei, M.L., Danovaro, R., 2004. Virus production and life strategies in aquatic sediments. Limnol. Oceanogr. 49, 459-470.

Moriarty, D.J.W., 1979. Biomass of suspended bacteria over coral reefs. Mar. Biol. 53, 193-200.

Moriarty, D.J.W., Pollard, P.C., Hunt, W.G., 1985. Temporal and spatial variation in bacterial production in the water column over a coral reef. Mar. Biol. 85, 285292.

Pagès, J., Andréfouët, S., Delesalle, B., Prasil, V., 2001. Hydrology and trophic state in Takapoto Atoll lagoon: comparison with other Tuamotu lagoons. Aquat. Living Res. 14, 183-193.

Patel, A., Noble, R.T., Steele, J.A., Schwalbach, M.S., Hewson, I., Fuhrman, J.A., 2007. Virus and prokaryote enumeration from planktonic aquatic environments by epifluorescence microscopy with SYBR Green I. Nat. Protoc. 2, 269-276.

Patten, N.L., Mitchell, J.G., Middelboe, M., Eyre, B.D., Seuront, L., Harrison, P.L., Glud, R.N., 2008. Bacterial and viral dynamics during a mass coral spawning period on the Great Barrier Reef. Aquat. Microb. Ecol. 50, 209-220.

Patten, N.L., Wyatt, A.S.J., Lowe, R.J., Waite, A.M., 2011. Upstage of picophytoplankton, bacterioplankton and virioplankton by a fringing cora reef community (Ningaloo Reef, Australia). Coral Reefs 30, 555-567.

Paul, J.H., DeFlaun, M.F., Jeffrey, W.H., 1986. Elevated levels of microbial activity in the coral surface microlayer. Mar. Ecol. Prog. Ser. 33, 29-40.

Paul, J.H., Rose, J.B., Jiang, S.C., Kellogg, C.A., Dickson, L., 1993. Distribution of viral abundance in the reef environment of Key Largo, Florida. Appl. Environ. Microbiol. 59, 718-724.

Porter, K.G., Feig, Y.S., 1980. The use of DAPI for identifying and counting aquatic microflora. Limnol. Oceanogr. 25, 943-948.

Pouvreau, S., Jonquières, G., Buestel, D., 1999. Filtration by the pearl oyster Pinctada margaritifera, under conditions of low seston load and small particles size in a tropical lagoon habitat. Aquaculture 176, 295-314.

Proctor, L.M., Fuhrman, J.A., 1990. Viral mortality of marine bacteria and cyanobacteria. Nature 343, 60-62.

Robarts, R.D., Zohary, T., 1993. Fact or fiction-bacterial growth rates and production as determined by (methyl-3H)-thymidine? Adv. Microb. Ecol. 13, 371-425.

Rochelle-Newall, E.J., Torréton, J.-P., Mari, X., Pringault, O., 2008. Phytoplanktonbacterioplankton coupling in a subtropical South Pacfic coral reef lagoon. Aquat. Microb. Ecol. 50, 221-229.

Rohwer, F., Seguritan, V., Azam, F., Knowlton, N., 2002. Diversity and distribution of coral associated bacteria. Mar. Ecol. Prog. Ser. 243, 1-10.

Seymour, J.R., Pattern, N., Bourne, D.G., Mitchell, J.G., 2005. Spatial dynamics of virus like particles and heterotrophic bacteria within a shallow coral reef system. Mar. Ecol. Prog. Ser. 288, 1-8.

Suttle, C.A., 2005. Viruses in the sea. Nature 437, 356-361.

Thingstad, T.F., 2000. Elements of a theory for the mechanisms controlling abundance, diversity and biogeochemical role of lytic bacterial viruses in aquatic systems. Limnol. Oceanogr. 45, 1320-1328.
Thomas, Y., Garen, P., Courties, C., Charpy, L., 2010. Spatial and temporal variability of the pico-and nanophytoplankton and bacterioplankton in a deep Polynesian atoll lagoon. Aquat. Microb. Ecol. 59, 89-101.

Torréton, J.P., 1999. Biomass, production and heterotrophic activity of bacterioplankton in the Great Astrolabe Reef lagoon (Fidji). Coral Reefs 18, 43-53.

Torréton, J.P., Dufour, P., 1996. Temporal and spatial stability of bacterioplankton biomass and productivity in an atoll lagoon. Aquat. Microb. Ecol. 11, 251-261.

Tuomi, P., Lundsgaard, C., Ekebom, J., Olli, K., Künnis, K., 1999. The production and potential loss mechanisms of bacterial biomass in the southern Gulf of Riga. J. Mar. Syst. 23, 185-196.

van Duyl, F.C., Gast, G.J., 2001. Linkage of small-scale spatial variations in DOC, inorganic nutrients and bacterioplankton growth with different coral reef water types. Aquat. Microb. Ecol. 24, 17-26.

Weil, E., Smith, G., Gil-Agudelo, D.L., 2006. Status and progress in coral reef disease research. Dis. Aquat. Org. 69, 1-7.

Weinbauer, M.G., 2004. Ecology of prokaryotic viruses. FEMS Microbiol. Rev. 28, 127-181.

Weinbauer, M.G., Fuchs, D., Peduzzi, P., 1993. Distribution of viruses and dissolved DNA along a coastal trophic gradient in the northern Adriatic Sea. Appl. Environ. Microbiol. 59, 4074-4082.

Weinbauer, M.G., Höfle, M.G., 1998. Size-specific mortality of lake bacterioplankton by natural virus communities. Aquat. Microb. Ecol. 15, 103-113.

Weinbauer, M.G., Peduzzi, P., 1995. Significance of viruses versus heterotrophic nanoflagellates for controlling bacterial abundance in the northern Adriatic Sea. J. Plankton Res. 17, 1851-1856.

Weinbauer, M.G., Winter, C., Hofle, M., 2002. Reconsidering transmission electron microscopy based estimates of viral infection of bacterioplankton using conversion factors derived from natural communities. Aquat. Microb. Ecol. 27, 103-110.

Weinbauer, M.G., Nedoma, J., Christaki, U., Simek, K., 2003. Comparing the effects of resource enrichment and grazing on viral production in a meso-eutrophic reservoir. Aquat. Microbiol. Ecol. 31, 137-144.

Weinbauer, M.G., Kerros, M.-E., Motegi, C., Wilhartiz, I.C., Rassoulzadegan, F., Torréton, J.-P., Mari, X., 2010. Bacterial community composition and potential controlling mechanisms along a trophic gradient in a barrier reef system. Aquat. Microb. Ecol. 60, 15-28.

Wild, C., Huettel, M., Klueter, A., Kremb, S.G., Rasheed, M.Y.M., Jorgensen, B.B., 2004. Coral mucus functions as an energy carrier and particle trap in the reef ecosystem. Nature 428, 66-70.

Wilhelm, S.W., Suttle, C.A., 1999. Viruses and nutrient cycles in the sea. Bioscience 49, 781-788.

Wommack, K.E., Colwell, R.A., 2000. Virioplankton: viruses in aquatic ecosystems. Microbiol. Mol. Biol. Rev. 64, 69-114.

Yentsch, C.S., Menzel, D.W., 1963. A method for the determination of phytoplankton, chlorophyll and phaeophytin by fluorescence. Deep-Sea Res. $10,221-231$. 